\title{
Distribution of Glucagon-Like Peptide (GLP)-2-Immunoreactive Cells in the Chicken Small Intestine: Antigen Retrieval Immunohistochemistry
}

\author{
Mohammad M. MONIR ${ }^{1)}$, Kohzy HIRAMATSU2)*, Kei NISHIMURA ${ }^{3)}$, Chihiro TAKEMOTO ${ }^{3)}$ and \\ Takafumi WATANABE ${ }^{2}$ \\ 1) Department of Bioscience and Food Production Science, Interdisciplinary Graduate School of Science and Technology, Shinshu \\ University, 8304 Minami-minowa, Kami-ina, Nagano 399-4598, Japan \\ ${ }^{2)}$ Laboratory of Animal Functional Anatomy (LAFA), Faculty of Agriculture, Shinshu University, Minami-minowa 8304, Kami-ina, \\ Nagano 399-4598, Japan \\ 3) Department of Food Production Science, Graduate School of Agriculture, Shinshu University, 8304 Minami-minowa, Kami-ina, Nagano \\ 399-4598, Japan
}

(Received 16 October 2013/Accepted 26 November 2013/Published online in J-STAGE 10 December 2013)

ABSTRACT. An antigen retrieval method for immunohistochemical staining of glucagon-like peptide (GLP)-2-immunoreactive cells was investigated in the chicken small intestine. GLP-2-immunoreactive cells were observed as open-typed endocrine cells in the villous epithelium and crypts on both antigen retrieval agent-treated and untreated preparations. No obvious differences were detected in morphological features of GLP-2-immunoreactive cells between treated and untreated preparations. The frequencies of occurrence of GLP-2-immunoreactive cells, however, were significantly different in treated and untreated preparations: in the proximal and distal regions of jejunum and ileum obtained from untreated preparations, the frequencies of occurrence were $0.5 \pm 0.2,0.7 \pm 0.1,0.9 \pm 0.2$ and $1.5 \pm 0.3$, respectively (cell numbers per mucosal area: cells $/ \mathrm{mm}^{2}$, mean $\pm \mathrm{SD}$ ), whereas those from treated sections were $14.7 \pm 2.3,19.8 \pm 2.3,23.5 \pm 4.7$ and 34.6 \pm 4.9 cells $/ \mathrm{mm}^{2}$, respectively. These data indicate that this antigen retrieval method is able to make immunoreactive GLP-2 available for detection and that GLP-2 may act as one of the common hormones secreted by L cells in the chicken small intestine.

KEY WORDS: antigen retrieval agent, chicken, glucagon-like peptide-2, immunohistochemistry, intestine.

doi: 10.1292/jvms.13-0513; J. Vet. Med. Sci. 76(4): 565-568, 2014

Glucagon-like peptide (GLP)-2, composed of 33 amino acids, is derived from proglucagon $[1,3,13]$. This mealinduced gut hormone exerts diverse actions in the gastrointestinal tract including stimulation of intestinal growth and upregulation of villus height, concomitant with crypt cell proliferation and reduction of enterocyte apoptosis [4]. GLP-2 has cytokine activities, enhancing cell differentiation, playing a role in tissue regeneration and mediating cytoprotection [2]. Also, in the chicken intestine, the proglucagon gene contains the sequence of GLP-2 and is spliced at the exon encoding this peptide [11]. Hu et al. [10] showed a positive effect of GLP-2 injection on the growth performance of healthy broiler chickens. Despite these biochemical and physiological data, there are no documented immunohistochemical reports regarding the distribution pattern of GLP-2-containing cells in the chicken intestine. It is possible that this gap between publication of immunohistochemical investigations and biochemical or physiological reports may be due to the masking of antigens by the immunohistochemical procedures, fixation or paraffin embedding

*Correspondence to: Hiramatsu, K., Ph. D., Laboratory of Animal Functional Anatomy (LAFA), Faculty of Agriculture, Shinshu University, 8304 Minami-minowa, Kami-ina, Nagano 399-4598, Japan. e-mail: seitaik@shinshu-u.ac.jp

(C)2014 The Japanese Society of Veterinary Science

This is an open-access article distributed under the terms of the Creative Commons Attribution Non-Commercial No Derivatives (by-nc-nd) License $<$ http://creativecommons.org/licenses/by-nc-nd/3.0/>.
[12]. We recently reported that many, but not all, intestinal L cells contained both GLP-1 and GLP-2 peptides in the same secretory granules [15]. More morphological data on GLP2-containing cells are necessary in order to understand the mechanism of GLP secretion. In this study, we examined a method for retrieval of immunoreactive GLP-2 antigen in L cells and used the method to clarify the distribution of GLP2-containing cells in the chicken small intestine.

Tissue samples of proximal and distal regions of jejunum and ileum were obtained from male White Leghorn chickens ( 9 weeks age, $\mathrm{n}=5$, average $\mathrm{BW}=667 \mathrm{~g}$ ). Chickens were treated in accordance with the "Guideline for Regulation of Animal Experimentation (1997)" of Faculty of Agriculture, Shinshu University. These tissue samples were embedded in paraffin in the ordinary manner after immersion in Bouin's fluid overnight at room temperature. Two groups of sections, cut at $5 \mu \mathrm{m}$ thickness, were made from each intestinal region. After removal of paraffin and rehydration, the samples of one group of sections were incubated with $0.5 \%$ antigen retrieval agent (citraconic anhydrate, Immunosaver ${ }^{\circledR}$, Nisshin EM, Tokyo, Japan) at $98^{\circ} \mathrm{C}$ for $45 \mathrm{~min}$ [7] and rinsed with phosphate buffered saline $(\mathrm{pH}$ 7.6). The other group was processed for ordinary immunohistochemistry without the incubation with antigen retrieval agent. The horseradish peroxidase-labeled streptavidin-biotin method [5] was applied to detect GLP-2-immunoreactive cells according to the procedure described previously [6]. All sections were treated with $10 \%$ normal goat serum (50062Z, Invitrogen, Carlsbad, CA, U.S.A.) for $20 \mathrm{~min}$ and then incubated with 


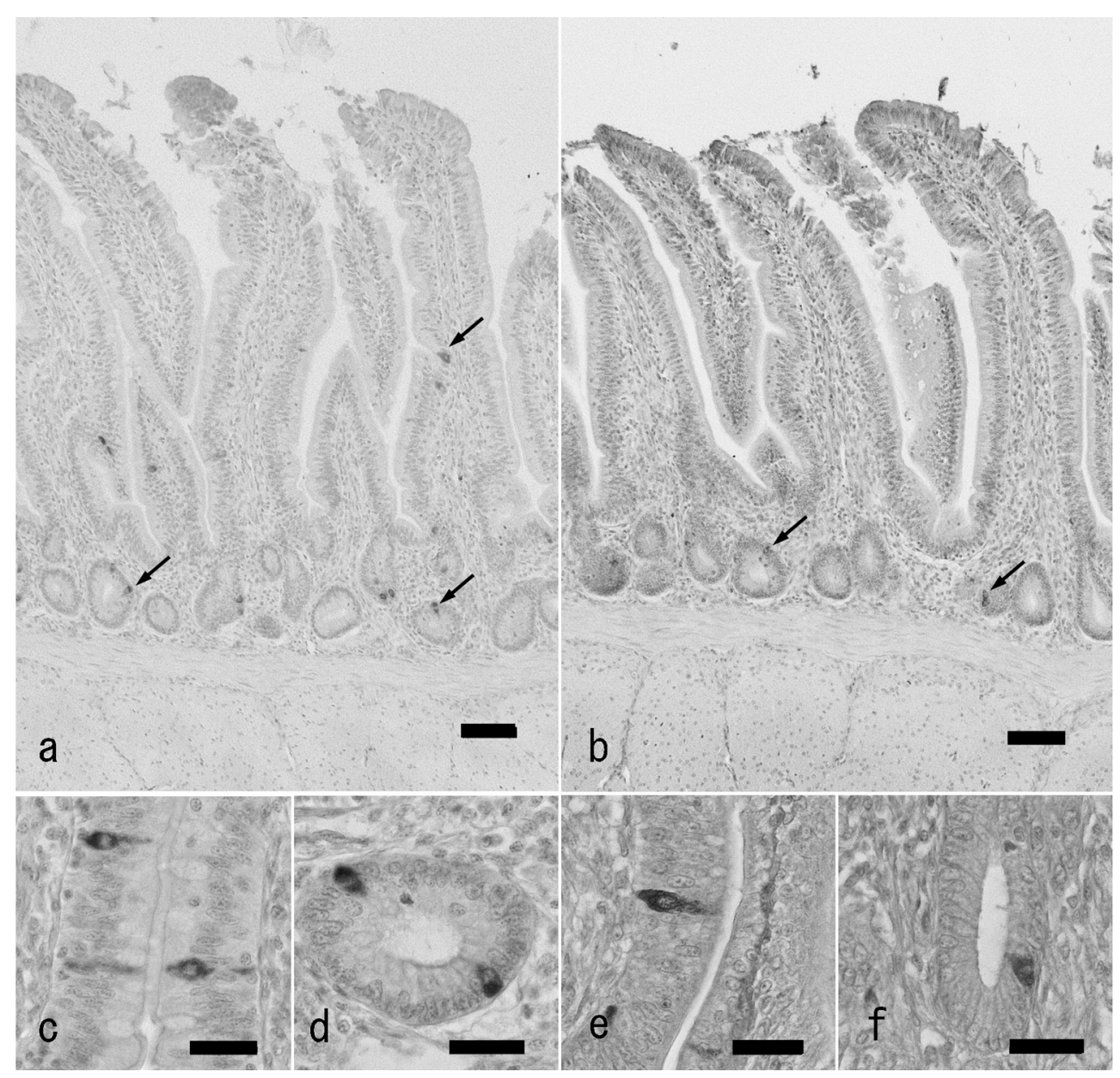

Fig. 1. GLP-2-immunoreactive cells in the chicken distal ileum of antigen retrieval agent-treated (a, c, d) and untreated sections (b, e, f). a: Localization of GLP-2-immunoreactive cells (arrows) in the distal ileum of antigen retrieval agent-treated section. Immunoreactive cells are located in the epithelium of the lower part of villi and crypts mainly. Bar: $50 \mu \mathrm{m}$. b: Localization of GLP-2-immunoreactive cells (arrows) in the chicken ileum of untreated sections. A small number of immunoreactive cells (arrows) are observed. c, d: High magnification views of GLP-2-immunoreactive cells in villous epithelium (c) and crypt (d) of antigen retrieval agent-treated sections. Bar: $20 \mu \mathrm{m}$. e, f: High magnification views of GLP-2-immunoreactive cells in villous epithelium (e) and crypt (f) of untreated sections. Bar: $20 \mu \mathrm{m}$.

rabbit anti-human ( $\left.\mathrm{Arg}^{34}\right)$-GLP-2 serum (1:2,000, H-028-14, Phenix Pharmaceuticals, Burlingame, CA, U.S.A.) for $24 \mathrm{hr}$. The immunocomplex was visualized with $0.05 \% 3,3^{\prime}$-diaminobenzidine in Tris-HCl buffer ( $\mathrm{pH} 7.6)$. Sections were counterstained with Mayer's hematoxylin and observed under a light microscope. The specificity of the primary antibody used in this study was documented by the manufacturer and in our previous study [15]. Sections for negative staining control were incubated with normal rabbit serum instead of the specific primary serum or without the specific primary serum. No specific reaction was observed in the control sections for the immunostaining.

The morphometric analysis was carried out by following a method previously described [9]. We only counted cells with clearly detectable nuclei, and the area of the mucosal layer was also measured accordingly. Then, the cell number per area of the mucosal layer (cells $/ \mathrm{mm}^{2}$ ) was calculated to find the frequency of occurrence of GLP-2- immunoreactive cells in each intestinal region. This computation was performed using a computerized image analyzing system (KS400, Zeiss, Göttingen, Germany). Twenty areas were measured in each intestinal region from each bird, i.e. 100 areas in total from 5 chickens of each group. Tukey's method [19] of statistical analysis was followed to assess the differences in the frequency of occurrence of GLP-2-immunoreactive cells. $P<0.05$ was set as the level of significance.

Endocrine cells showing immunoreactivity with GLP-2 antiserum were identified in the whole jejunum and ileum from both groups (Fig. 1a and 1b). GLP-2-immunoreactive cells were distributed in the epithelium of intestinal villi and crypts as open-typed endocrine cells. In the ileum, they were located in the lower part of intestinal villi, but in the 
proximal jejunum, they were located from the middle to the lower parts. Most of the endocrine cells showing GLP2-immunoreactivity had a pyramidal or spindle-like shape in the villous epithelium (Fig. 1c and 1e) and a comma-like shape in the crypts (Fig. 1d and 1f). Thus, there were no apparent differences between the two groups of sections in morphological features and distribution patterns of GLP-2-immunoreactive cells. There were, however, significant differences in the frequency of occurrence of GLP2-immunoreactive cells between the two groups (Fig. 2). In the proximal and distal parts of the jejunum and ileum, the values obtained from untreated sections were $0.5 \pm 0.2,0.7$ $\pm 0.1,0.9 \pm 0.2$ and $1.5 \pm 0.3$, respectively (cell numbers per mucosal area: cells $/ \mathrm{mm}^{2}$, mean $\pm \mathrm{SD}$ ). In contrast, the values from the corresponding areas treated with antigen retrieval agent were $14.7 \pm 2.3,19.8 \pm 2.3,23.5 \pm 4.7$ and $34.6 \pm 4.9$ cells $/ \mathrm{mm}^{2}$, respectively. In both cases, frequencies of occurrence of GLP-2-immunoreactive cells were gradually and significantly increased with the advancement to the distal region of the small intestine.

Thus, the frequencies of occurrence of GLP-2-immunoreactive cells obtained from preparations treated with antigen retrieval agent were significantly higher than those from untreated preparations. These values are also higher than those of GLP-1-immunoreactive cells that we reported previously, but they showed a similar distribution pattern to that of GLP-1 [14]. The reason for this discrepancy may be that an antigen retrieval agent was not used in our previous investigation of GLP-1. These findings indicate that the epitope of GLP-2 is masked in intestinal L cells and that immunoreactivity for GLP-2 is difficult to detect by the ordinary procedure for immunohistochemical staining. The fixative may be the main reason for this phenomenon. Paraformaldehyde (polyoxymethylene) forms methylene bridges between proteins, which can hinder epitope recognition by the primary antibodies. The heat-induced epitope retrieval method is a common approach to expose the antigen epitopes in preparations for immunohistochemical staining. If this step is not performed, the antibodies will not have complete access to the tissue and will be unable to bind to the correct epitope. Antigen retrieval leads to satisfactory immunohistochemical staining in paraffin-embedded tissue for a great number of antibodies tested [16-18]. An apparent difference in the condition of immunohistochemical staining was ascertained between GLP-1 and GLP-2. Immunohistochemical staining for GLP-1 proceeded relatively well without the treatment with antigen retrieval agent $[8,9,14]$. But, in this case, immunohistochemical staining for GLP-2 showed very small numbers of endocrine cells even in the same samples as those used for GLP-1 immunohistochemistry. Antigen retrieval is thus a necessary process at least for detection of GLP-2 immunoreactivity in the chicken intestine.

This study determined the distribution pattern of GLP2-containing intestinal L cells in the chicken small intestine. Immunoreactive cells for GLP-2 were mainly observed in the crypts of the distal ileum followed by the proximal jejunum. This distribution pattern is similar to that of GLP1-immunoreactive cells. Our recent investigation using

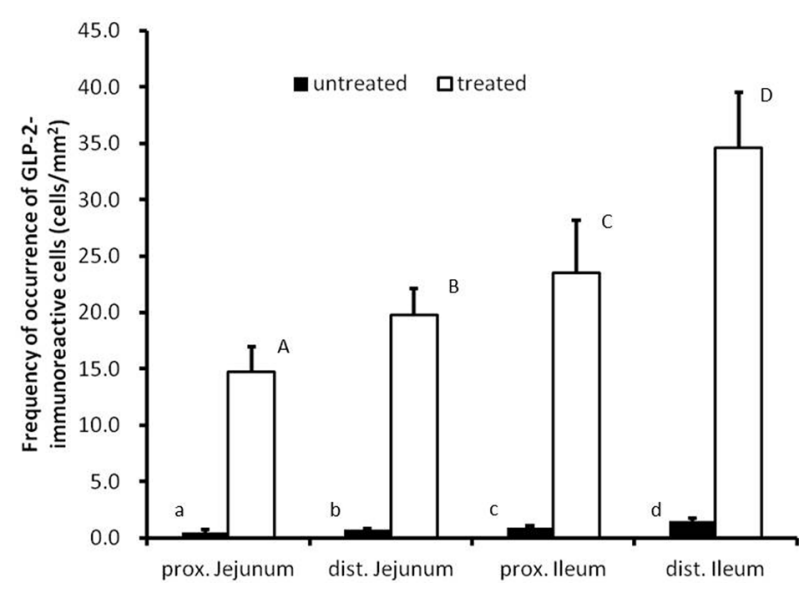

Fig. 2. Frequencies of occurrence of GLP-2-immunoreactive cells in the chicken small intestine of antigen retrieval agent-treated and untreated sections. Values represent mean numbers of GLP2 -immunoreactive cells per $1 \mathrm{~mm}^{2}$ of mucosa. There are significant differences between different alphabets $(P<0.05$, error bars: SD).

immunocytochemistry with colloidal gold determined the colocalization of GLP-1 and GLP-2 in the same secretory granules [15]. The similarity of the distribution patterns of GLP-1 and GLP-2 is supported by this immunocytochemical study. There is a difference, however, between these two peptides in the localization of immunoreactive cells in the ileum. GLP-2-immunoreactive cells are mainly located in the epithelium of the lower part of intestinal villi, while GLP-1-immunoreactive cells are located in the middle to lower parts of intestinal villi $[8,9,14]$. Our immunocytochemical study showed L cells containing only GLP-1 peptide in the villous epithelium of the chicken ileum [15]. The difference in localization of GLP-1 and GLP-2 reflects this finding. Biochemical and molecular biological studies of the secretory process of GLPs may be necessary to clarify this phenomenon.

\section{REFERENCES}

1. Burrin, D. G., Stoll, B. and Guan, X. 2003. Glucagon-like peptide 2 function in domestic animals. Domest. Anim. Endocrinol. 24: 103-122. [Medline] [CrossRef]

2. Drucker, D. J. 2003. Glucagon-like peptides: regulators of cell proliferation, differentiation, and apoptosis. Mol. Endocrinol. 17: 161-171. [Medline] [CrossRef]

3. Drucker, D. J. 2005. Biologic actions and therapeutic potential of the proglucagon-derived peptides. Nat. Clin. Pract. Endocrinol. Metab. 1: 22-31. [Medline] [CrossRef]

4. Guan, X., Karpen, H. E., Stephens, J., Bukowski, J. T., Niu, S., Zhang, G., Stoll, B., Finegold, M. J., Holst, J. J., Hadsell, D. L., Nochols, B. L. and Burrin, D. G. 2006. GLP-2 receptor localizes to enteric neurons and endocrine cells expressing vasoactive peptides and mediates increased blood flow. Gastroenterology 130: 150-164. [Medline] [CrossRef]

5. Guesdon, J.L., Ternynck, T. and Avrameas, S. 1979. The use of avidin-biotin interaction in immunoenzymatic techniques. $J$. Histochem. Cytochem. 27: 1131-1139. [Medline] [CrossRef] 
6. Hiramatsu, K. and Ohshima, K. 1995. Immunohistochemical study on the distribution of galanin-containing nerves in the chicken pancreas. Histol. Histopathol. 10: 283-288. [Medline]

7. Hiramatsu, K., Nagao, K. and Kita, K. 2005. Localization of insulin-like growth factor I (IGF-I) in the chicken liver after fasting and refeeding: demonstration by using antigen retrieval immunohistochemistry. J. Vet. Med. Sci. 67: 393-397. [Medline] [CrossRef]

8. Hiramatsu, K., Yamasaki, A. and Karasawa, Y. 2003. Comparative study on the distribution of glucagon-like peptide-1 (GLP-1)-immunoreactive cells in the intestine of chicken and ostrich. J. Poult. Sci. 40: 39-44. [CrossRef]

9. Hiramatsu, K., Yamasaki, A. and Shioji, T. 2005. Immunohistochemical and morphometrical studies on the distribution of glucagon-like peptide-I (GLP-I)-immunoreactive cells in the chicken intestine. J. Poult. Sci. 42: 223-229. [CrossRef]

10. Hu, X. F., Guo, Y. M., Huang, B. Y., Bun, S., Zhang, L. B., Li, J. H., Liu, D., Long, F. Y., Yang, X. and Jiao, P. 2010. The effect of glucagon-like peptide 2 injection on performance, small intestinal morphology, and nutrient transporter expression of stressed broiler chickens. Poult. Sci. 89: 1967-1974. [Medline] [CrossRef]

11. Irwin, D. M. and Wong, J. 1995. Trout and chicken proglucagon: alternative splicing generates mRNA transcripts encoding glucagon-like peptide 2. Mol. Endocrinol. 9: 267-277. [Medline] [CrossRef]

12. Jiao, Y., Sun, Z., Lee, T., Fusco, F. R., Kimble, T. D., Meade, C. A., Cuthbertson, S. and Reiner, A. 1999. A simple and sensitive antigen retrieval method for free-floating and slide-mounted tissue sections. J. Neurosci. Methods 93: 149-162. [Medline] [CrossRef]

13. Lovshin, J. and Drucker, D. J. 2000. New frontiers in the biology of GLP-2. Regul. Pept. 90: 27-32. [Medline] [CrossRef]

14. Monir, M. M., Hiramatsu, K., Yamasaki, A., Nishimura, K. and Watanabe, T. 2013. The influence of restricted feeding on glucagon-like peptide-1 (GLP-1)-containing cells in the chicken small intestine. Anat. Histol. Embryol. [CrossRef]. [Medline]

15. Nishimura, K., Hiramatsu, K., Monir, M. M., Takemoto, C. and Watanabe, T. 2013. Ultrastructural study on colocalization of glucagon-like peptide (GLP)-1 with GLP-2 in chicken intestinal L-cells. J. Vet. Med. Sci. 75: 1335-1339. [Medline] [CrossRef]

16. Shi, S.R. and Taylor, C. R. 2010. Extended application of antigen retrieval technique in immunohistochemistry and in situ hybridization. pp. 25-45. In: Antigen Retrieval Immunohistochemistry Based Research and Diagnostics (Shi, S.-R. and Taylor, C. R. eds.), John Wiley \& Sons, New Jersey.

17. Taylor, C. R., Shi, S.R. and Barr, N. J. 2010. Techniques of immunohistochemistry: principles, pitfalls, and standardization. pp. 1-41. In: Diagnostic Immunohistochemistry: Theranostic and Genomic Applications. 3rd ed., (Dabbs, D. J. ed.), SaundersElsevier, Philadelphia.

18. Yamashita, S. 2007. Heat-induced antigen retrieval: mechanisms and application to histochemistry. Prog. Histochem. Cytochem. 41: 141-200. [Medline] [CrossRef]

19. Yanai, H. 2011. Statcel- The Useful Addin Forms on Excel, 3rd ed., OMS Publications, Tokorozawa (in Japanese). 